\title{
Colombia: Review Under the Flexible Credit Line-Staff Report; Press Release on the Executive Board Discussion; and Statement by the Executive Director for Colombia
}

In the context of the Colombia-Review Under the Flexible Credit Line, the following documents have been released and are included in this package:

- $\quad$ The staff report on the arrangement for Colombia Review Under the Flexible Credit Line, prepared by a staff team of the IMF, following discussions with the officials of Colombia on economic developments and policies that ended on October 28, 2009. Based on information available at the time of these discussions, the staff report was completed on October 28, 2009. The views expressed in the staff report are those of the staff team and do not necessarily reflect the views of the Executive Board of the IMF.

- $\quad$ A Press Release summarizing the views of the Executive Board as expressed during its October 28, 2009 discussion of the staff report that completed the request.

- A statement by the Executive Director for Colombia.

The policy of publication of staff reports and other documents allows for the deletion of market-sensitive information.

\author{
Copies of this report are available to the public from \\ International Monetary Fund $\bullet$ Publication Services \\ $70019^{\text {th }}$ Street, N.W. • Washington, D.C. 20431 \\ Telephone: (202) 623-7430 • Telefax: (202) 623-7201 \\ E-mail: publications@imf.org • Internet: http://www.imf.org
}

Price: $\$ 18.00$ a copy

\section{International Monetary Fund Washington, D.C.}


INTERNATIONAL MONETARY FUND

COLOMBIA

\section{Review Under the Flexible Credit Line Arrangement}

Prepared by the Western Hemisphere Department

(In consultation with other departments)

Approved by Miguel A. Savastano and Tessa van der Willigen

October 14, 2009

- Background. Last May, at a time of heightened global uncertainty, the Fund approved an FCL arrangement for Colombia (SDR 6.966 billion; 900 percent of quota) as an additional bolster to confidence in the country's strong framework for monetary and fiscal policies. Although tail risks to the global environment have not materialized, the FCL has provided additional coverage against adverse balance of payments shocks and increased the scope for countercyclical policies.

- Recent Developments and Outlook. The global environment has generally improved since approval of the FCL, resulting in better prospects for Colombia's balance of payments than previously anticipated. The peso has appreciated while the stock market has rebounded, and sovereign spreads have declined. Activity has stabilized and real GDP is projected to remain virtually flat in 2009 and grow about $2 \frac{1}{2}$ percent in 2010 . Inflation is expected to converge rapidly to the 2-4 percent long-term target.

- FCL qualification. The staff assess that Colombia continues to meet the qualification criteria for access to FCL resources specified under the Board decision on FCL arrangements (Decision No. 14283-(09/29), adopted March 24, 2009) and therefore recommends that the Board complete the review under the FCL arrangement, which would allow Colombia to make purchases before the expiration of the arrangement on May 10, 2010.

- Team. This report was prepared by a staff team led by Marco Piñón and comprising Enrique Flores, Laura Jaramillo (WHD), and Manrique Saenz (SPR). 


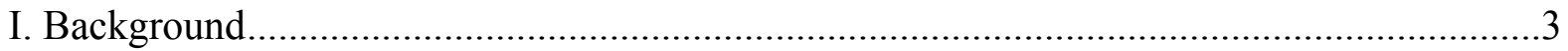

II. Developments and Policies Since the Approval of the FCL ...........................................

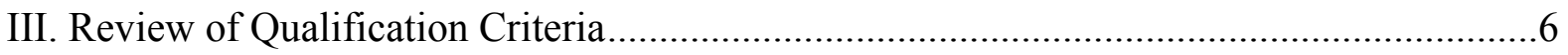

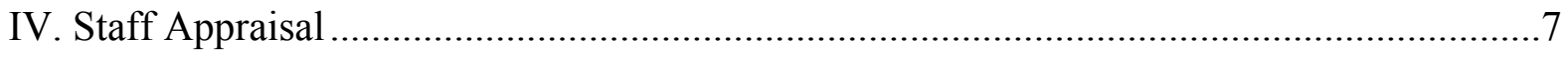

Tables

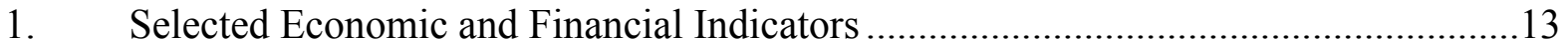

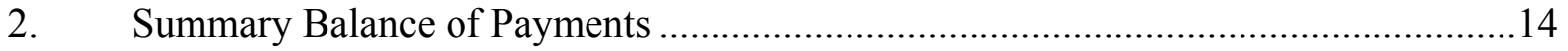

3. External Financing Requirements and Sources ..................................................... 15

4. Operations of the Combined Public Sector.......................................................... 16

5. Financial Soundness Indicators Total Banking System........................................ 17

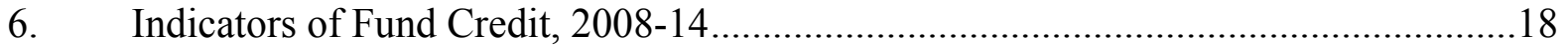

7. External Debt Sustainability Framework, 2004-14 ................................................19

8. Public Sector Debt Sustainability Framework, 2004-2014 ....................................20

Figures

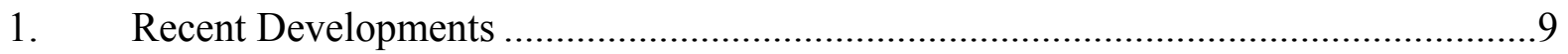

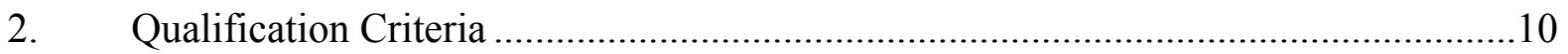

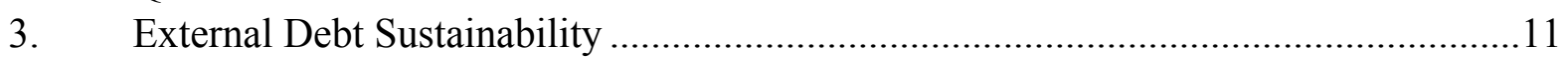

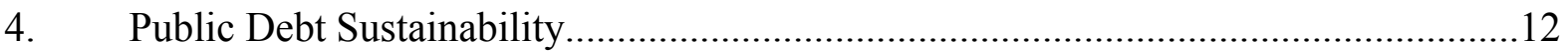




\section{BACKGROUND}

1. On May 11, 2009 the IMF Executive Board approved an FCL arrangement for Colombia for 900 percent of quota (SDR 6.966 billion, or about US\$11 billion) to bolster confidence in the country's policy and institutional frameworks at a time of heightened global uncertainty. It was envisaged that Colombia's strong institutional policy framework, including its flexible exchange rate, inflation targeting regime and medium term fiscal framework, would enable the authorities to adopt countercyclical policies to mitigate the adverse effects of the crisis on domestic demand. The FCL arrangement was intended to provide additional protection to the balance of payments while those policies were being pursued. Developments since the FCL approval have been generally positive and the authorities continue to treat the FCL resources as precautionary.
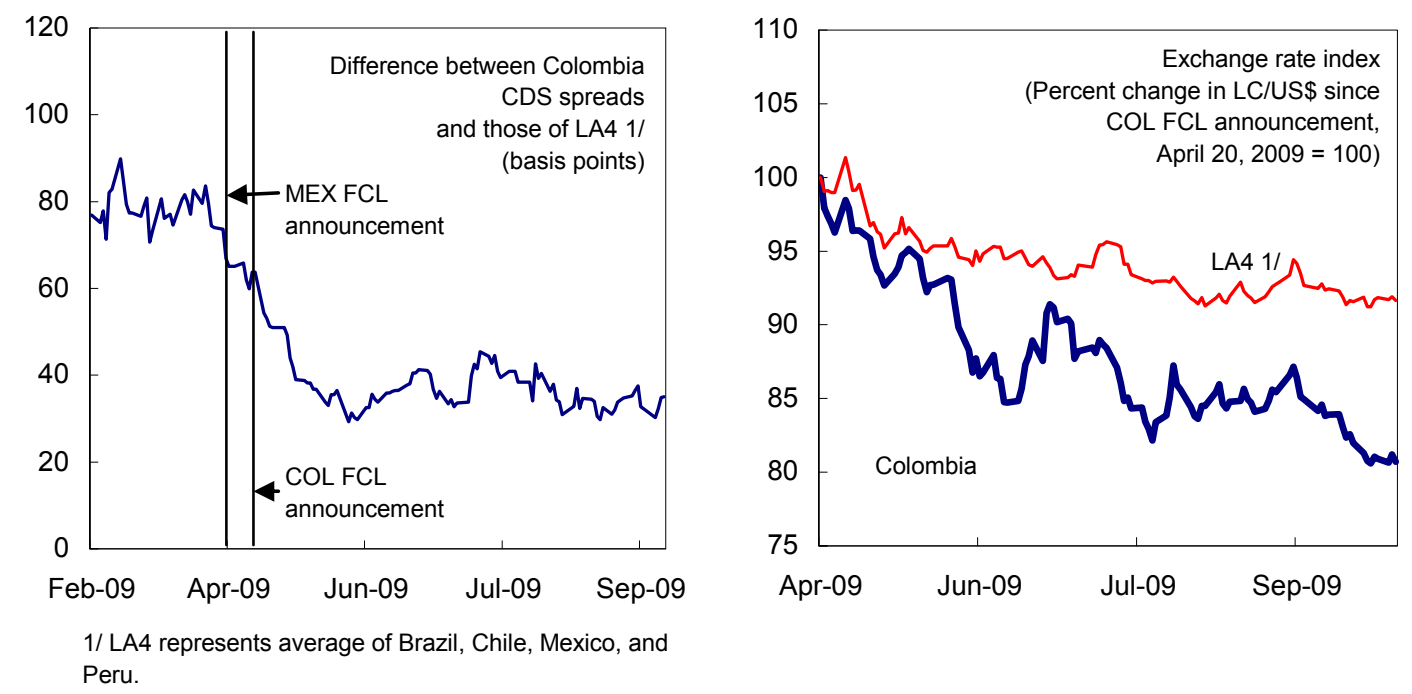

\section{Developments And Policies Since the Approval of the FCL}

2. The global environment has generally improved since May. The world economic downturn is showing signs of bottoming out, global financial conditions have improved, and commodity prices have recovered. Since April, emerging markets spreads have narrowed and private portfolio inflows have resumed. Equity prices in the region have rebounded - in some countries by over 40 percent - with Colombia's stock market index returning to pre-Lehman levels by end-June. EMBI spreads for Latin American countries fell by about 135 basis points (160 basis points for Colombia) from April to September. In addition, downside risks to commodity prices have abated, and oil prices have increased by 42 percent. (Figure 1) 

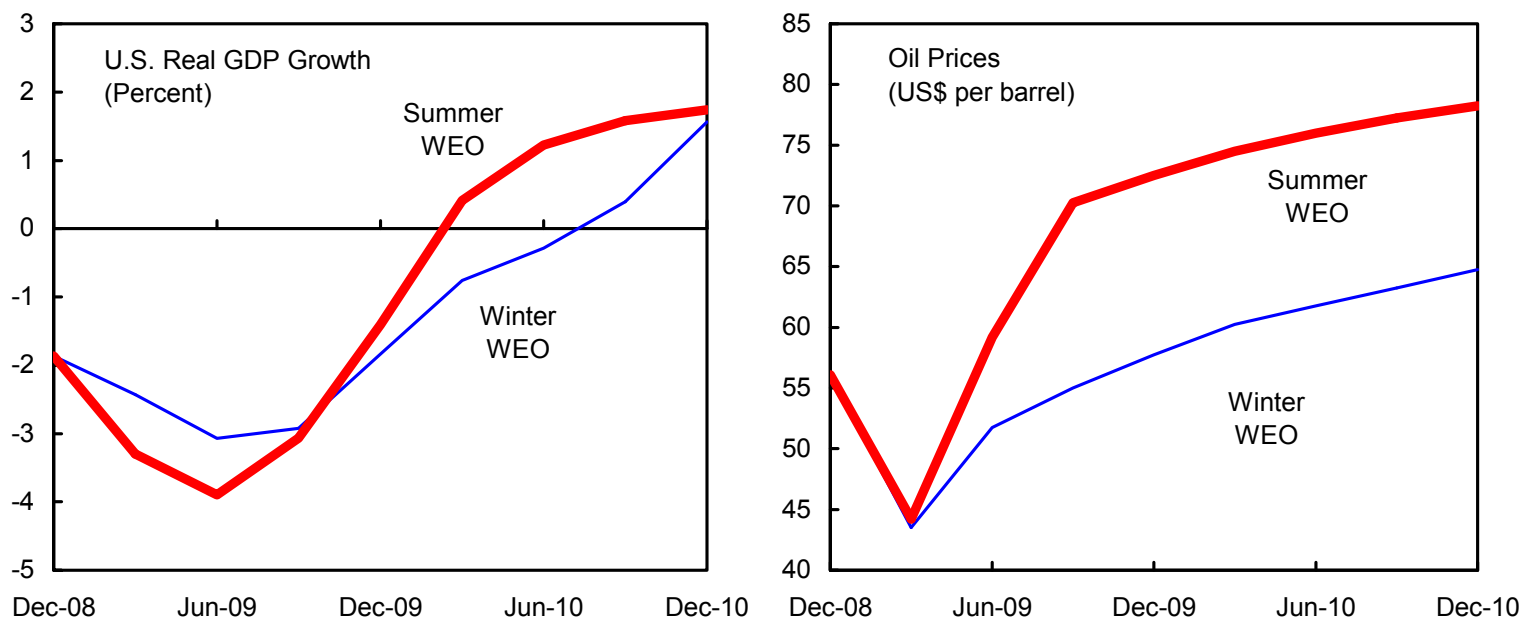

3. Since the FCL approval, the peso has strengthened, while gross international reserves have increased moderately. Following a sharp depreciation at the height of the crisis, the peso appreciated by 16 percent between April and end-September, and is now at its pre-Lehman levels. Central bank intervention has been small and gross international reserves have increased to US\$25 billion, largely on account of the SDR allocation to Colombia of SDR 624 million. Exchange rate volatility, however, continues to be somewhat higher than in other inflation targeting countries in the region.

\section{The upturn in the global environment has improved the balance of payments}

outlook. The external current account deficit in 2009 is now envisaged to remain at 3 percent of GDP — owing largely to a less severe decline in exports and remittances - compared to a projected deficit of almost 4 percent at the time of the FCL request. While the capital account is projected at similar levels to those of last May, its composition has shifted somewhat due to favorable external market conditions. Public sector roll-over rates have been higher than anticipated, at 300 percent in the first half of 2009. This includes US\$2 billion in bonds issued by public sector enterprises in July (proceeds of which so far have been kept abroad). Medium-term rollover rates for the private sector have been in line with expectations, some of which has been used to accumulate foreign assets. Looking ahead to 2010, exports are projected to rise together with import demand, keeping the current account balance broadly stable as a percent of GDP, and mostly financed by FDI. ${ }^{1}$

\footnotetext{
${ }^{1}$ The improved balance of payments outlook has strengthened Colombia's capacity to repay the Fund compared to when the FCL was approved. As of end-September, Colombia's FCL would reduce the Fund's Forward Commitment Capacity (FCC) by about 5 percent.
} 


\section{The recovery of economic activity} appears to have started. After posting negative growth in the second half of 2008, seasonally adjusted GDP has grown modestly in the first two quarters of 2009, largely driven by public investment. Supportive macroeconomic policies and larger than expected net exports would prevent a decline of real GDP in 2009 and sustain growth of about $2 \frac{1}{2}$ percent in 2010 , somewhat higher than previously projected.

\section{The financial system has continued to} show resilience. Capital adequacy and liquidity ratios have remained strong. Banks' portfolios have deteriorated modestly, with nonperforming loans increasing by 0.6 percentage points from September 2008 to August 2009 to 4.7 percent of loans. Bank credit growth has slowed but is still positive in real terms, and the corporate sector has secured financing through bond issuances in the local market.

\section{Monetary policy has remained on an} easing cycle while inflation expectations have remained anchored. With an additional reduction of 300 basis points since April, for a total of 600 basis points since December 2008, the policy rate stands at 4 percent as of end-September. At the same time, inflation fell to 3.1 percent in August, well below the 2009 target range of 4.5-5.5 percent. End-year inflation is now projected at $3 \frac{1}{2}$ percent, and a broadly similar outcome is expected for end2010. In its latest public statement on September 25, however, the central bank signaled an end to the easing cycle - barring a deterioration of the growth outlook - citing inflation expectations entrenched too close to the upper limit of the long-term 2-4 percent target.

\section{The fiscal deficit has increased at the expected pace, while financing remains} ahead of schedule. In the first quarter of 2009, weak revenues and expenditure execution in line with the budget resulted in an overall fiscal deficit to 0.2 percent of GDP. Colombia's placements of international bonds plus multilateral disbursements more than covered all the government's external financing needs, while domestic borrowing is proceeding ahead of schedule. Staff projects an overall fiscal deficit of 3.1 percent of GDP for the year as a whole.

\section{For 2010, the budget proposal presented to Congress in July targets an overall} deficit that is broadly similar to the one previously envisaged. Using staff's 
macroeconomic assumptions, the overall fiscal deficit in 2010 would remain at 3 percent of GDP, with income tax and oil related revenues remaining weak and total spending remaining stable in real terms (thus falling as a share of GDP). The authorities already have secured a portion of their 2010 external financing needs and have announced plans to further advance on this front before the end of the year.

10. Under the medium term framework presented to Congress, fiscal consolidation will restart in 2011. Using the latest WEO assumptions, the authorities' framework would yield rising revenues beyond 2011 (including through a postponing a phasing out of the wealth tax and higher oil related revenues) and broadly stable expenditures. As a result, the overall fiscal deficits would narrow gradually to 0.7 percent of GDP in 2014, and the public debt-to-GDP ratio would fall close to the medium-term path discussed during the 2008 Article IV consultation. ${ }^{2}$

\section{REVIEW OF QUALIFICATION CRITERIA}

\section{The staff assess that Colombia continues to meet the qualification criteria} identified in paragraph 2 of the FCL decision. Developments in Colombia since the approval of the FCL last May have not weakened its sound institutional and policy frameworks. The authorities have continued to implement very strong policies in line with policy frameworks described in the letter attached to IMF Country Report No. 09/153.

- $\quad$ Sustainable external position. Staff's updated debt sustainability analysis suggests that external debt ratios will decline when the crisis subsides and would remain manageable even under significantly negative shocks. The external current account deficit is projected to narrow and be financed mostly by FDI.

- $\quad$ Capital account position dominated by private flows. Despite a transitory pick up in government external borrowing, capital account flows are predominantly private - mostly in the form of FDI.

- $\quad$ Track record of steady sovereign access to international capital markets at favorable terms. The government was able to borrow from international markets at favorable terms in early 2009 when markets were unsettled. While the central government has not borrowed from markets since the FCL was approved, sovereign CDS spreads have narrowed substantially. Moreover, public enterprises have tapped the market at favorable terms.

\footnotetext{
${ }^{2}$ IMF Country Report No. 09/23, available at: www.imf.org
} 
- $\quad$ Relatively comfortable reserve position. Reserve coverage remains adequate at almost 7 months of imports and over 200 percent of short-term external debt on a remaining maturity basis.

- $\quad$ Sound public finances, including a sustainable public debt position. The authorities' revised medium-term fiscal framework underscores their commitment to debt reduction. Staff's updated debt sustainability analysis suggests that public debt would remain manageable and on a downward trajectory under alternative adverse scenarios.

- Low and stable inflation, in the context of a sound monetary and exchange rate policy framework. Inflation is expected to converge to within its longterm target range of 2-4 percent in 2009, and the authorities remain committed to the inflation targeting framework and the flexible exchange rate regime.

- $\quad$ Absence of systemic bank solvency problems that pose an imminent threat of a systemic banking crisis. Capital adequacy ratios remain strong at 15.3 percent and provisions amount to 117 percent of loans, while the deterioration of loans has been moderate.

- $\quad$ Effective financial sector supervision. Colombia's regulatory and supervisory framework remains strong, with a well established financial safety net. Last May, the Superintendency allocated more resources to on-site supervision in order to detect early on any deterioration of credit quality.

- Data transparency and integrity. The overall quality of Colombian macroeconomic data remains as described in the 2006 data ROSC. Colombia remains in observance of the Special Data Dissemination Standard (SDDS).

12. The staff did not become aware of any significant safeguards issues during the conduct of the FCL safeguards procedures related to Banco de la República (Colombia's central bank).

\section{Staff Appraisal}

\section{The FCL arrangement has provided Colombia an additional coverage against} adverse external shocks, in the context of strong monetary and fiscal policies.

Colombia's very strong institutional and policy frameworks (including its flexible exchange rate, inflation targeting framework, medium term fiscal framework, and relatively low debt levels) created the scope to support domestic demand with prudently expansionary macroeconomic policies. The resources from the FCL helped bolster confidence in the country's ability to withstand additional external shocks while carrying on those policies. 
14. In the staff's view, Colombia continues to fully meet the FCL qualification

criteria. Colombia's very strong fundamentals and institutional frameworks, as well as its proven track record - including since the approval of the FCL — underscores the authorities' commitment to adhere to sound policies and to react appropriately if the global environment deteriorates and new balance of payments difficulties were to arise. Thus, the staff recommends completion of the review under the FCL arrangement for Colombia. 
Figure 1. Colombia: Recent Developments

Sovereign spreads have narrowed...

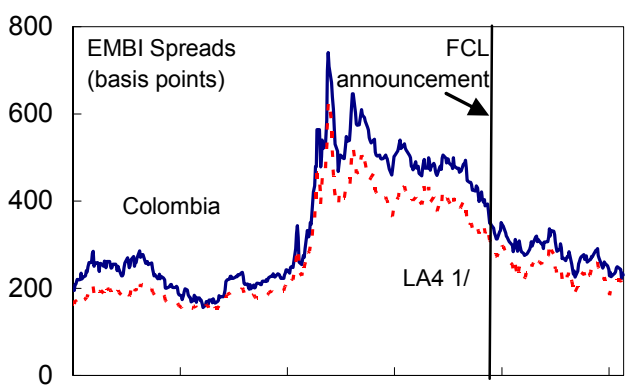

Dec-07 May-08 Sep-08 Jan-09 May-09 Sep-09

The slowdown in activity has leveled...

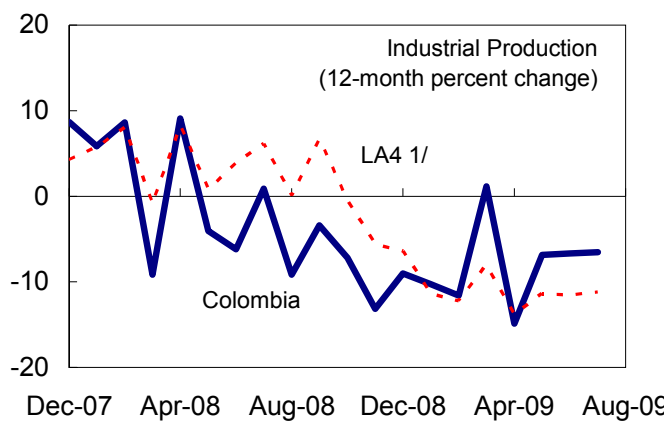

The external current account balance is improving...

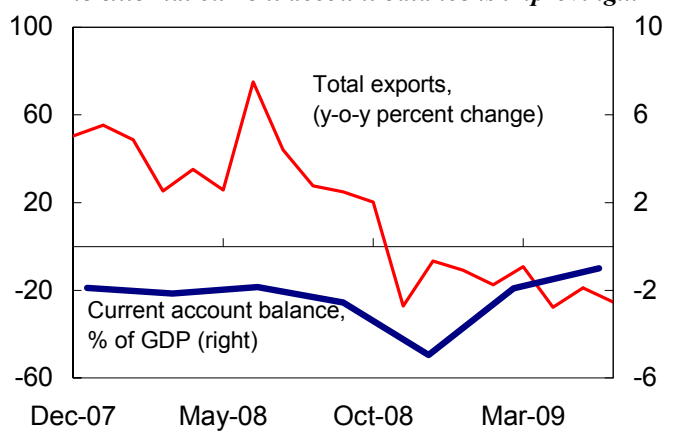

International reserves have remained broadly stable...

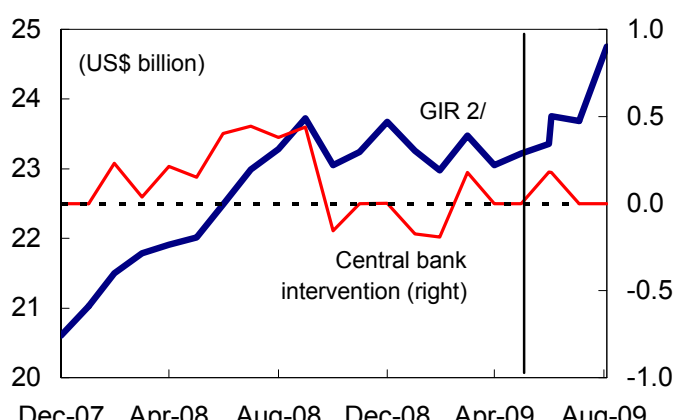

... and equity prices have recovered.

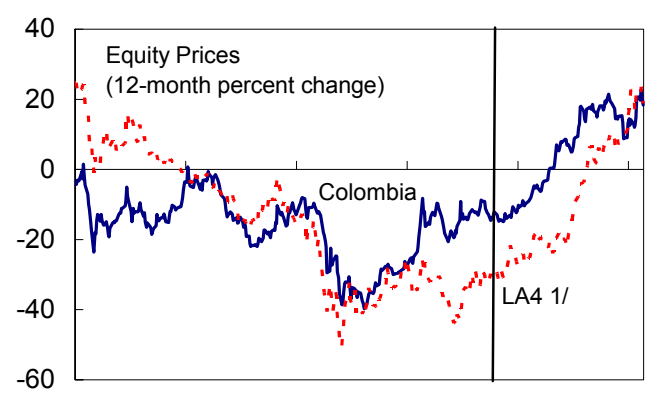

Dec-07 May-08 Sep-08 Jan-09 May-09 Sep-09

...though tax revenues continue to be weak.

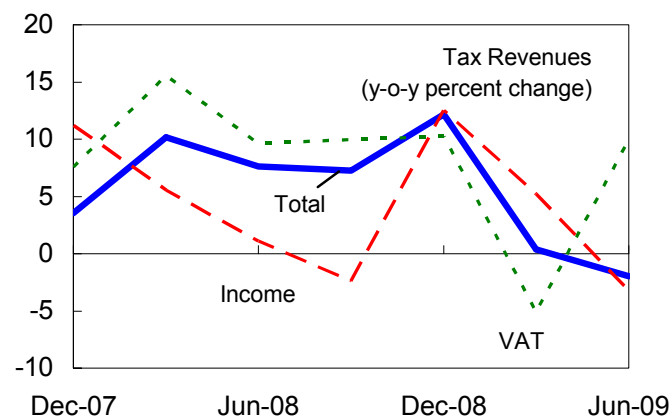

...and the peso has appreciated.

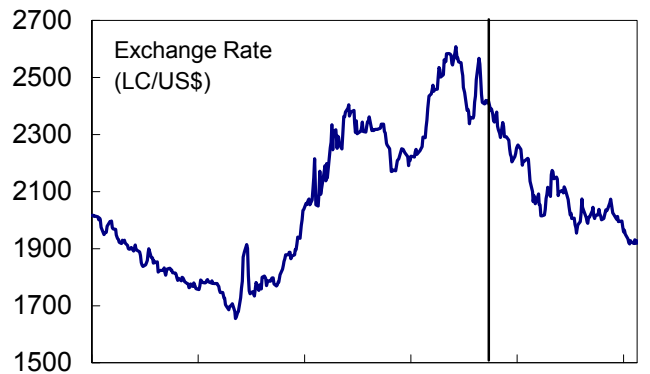

Dec-07 May-08 Sep-08 Jan-09 May-09 Sep-09

...while inflation has continued to decline.

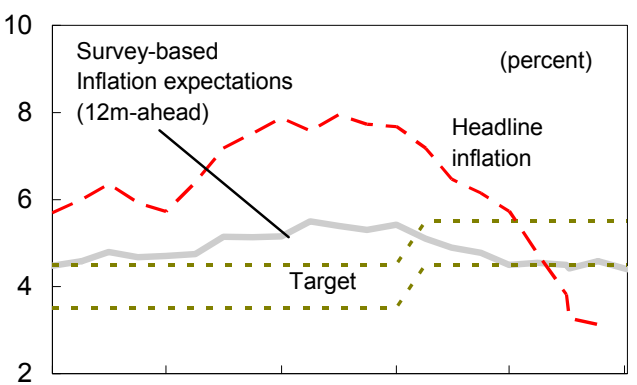

Dec-07 Apr-08 Aug-08 Dec-08 Apr-09 Aug-09

Sources: Banco de la República; Department of National Statistics; Bloomberg; Haver; and Fund staff calculations. 1/ LA4 represents the average of Brazil, Chile, Mexico, and Peru.

2/ Gross international reserves include the SDR allocation to Colombia on August 28, 2009 amounting to US $\$ 972$ million. 
Figure 2. Colombia: Qualification Criteria

Low and sustainable external debt.

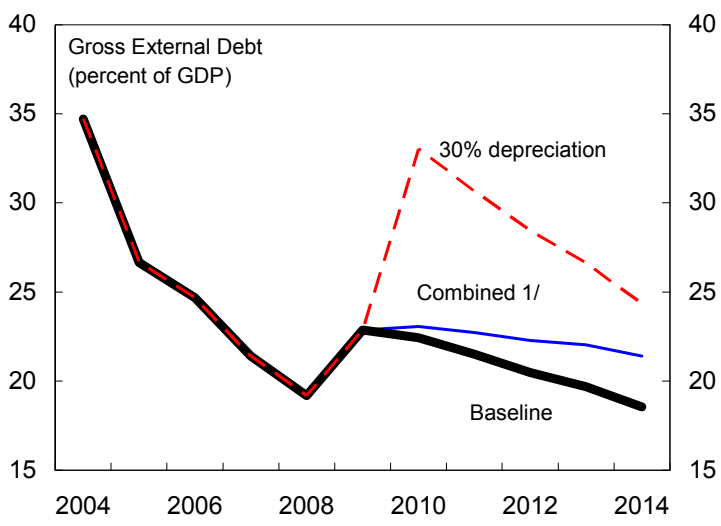

Uninterrupted access to capital markets.

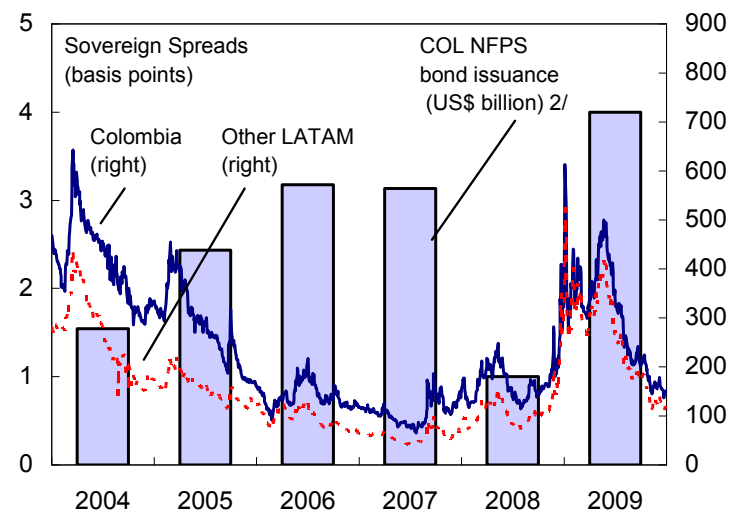

Sustainable public debt dynamics.

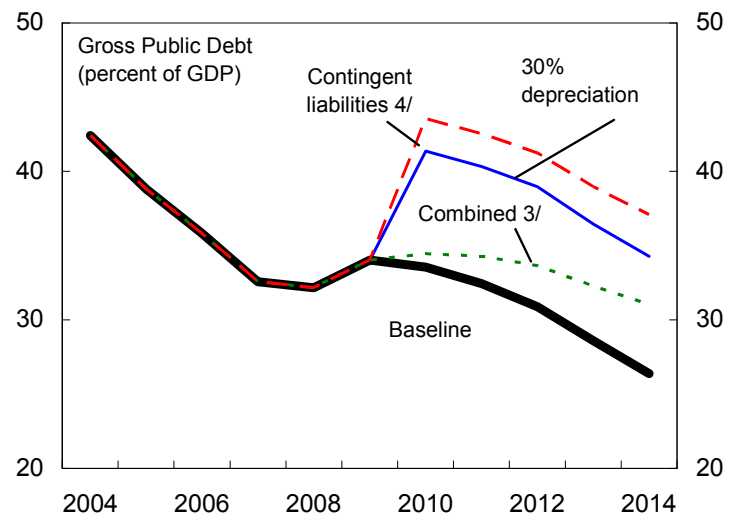

Nonresident claims concentrated in FDI.

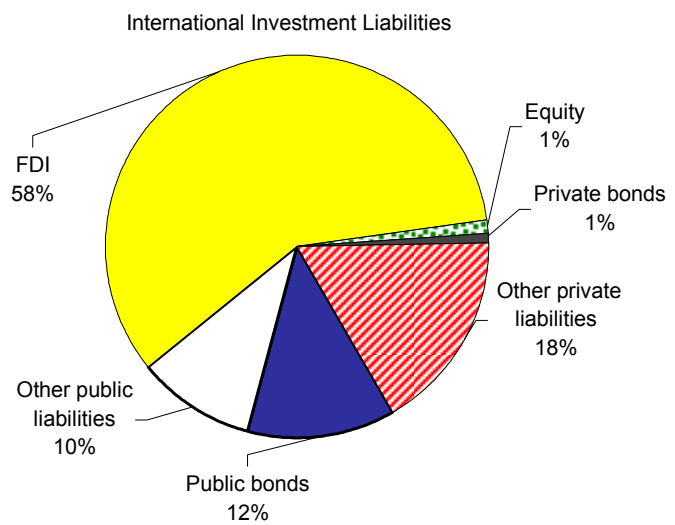

Comfortable reserve coverage.

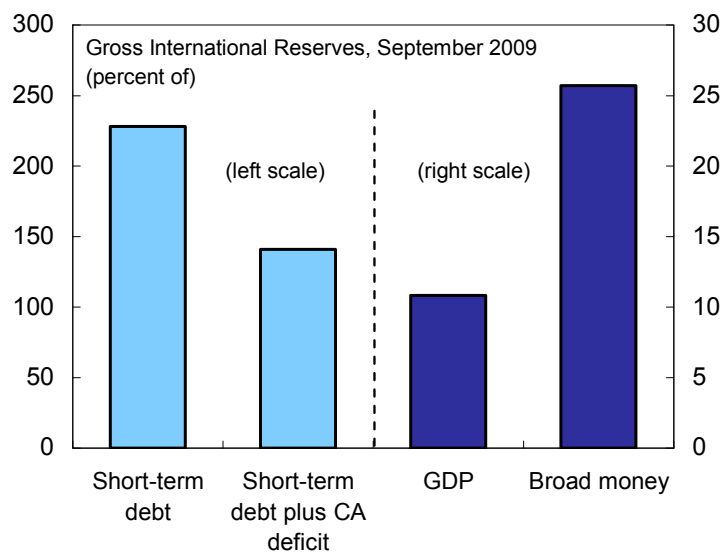

Relatively low inflation.

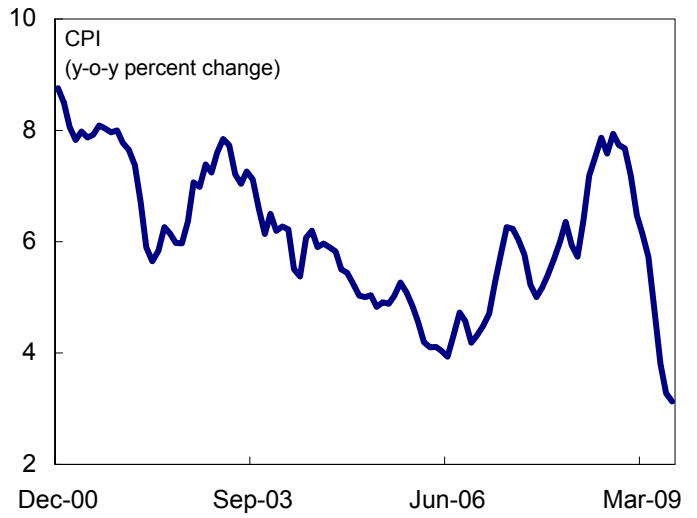

Sources: Banco de la Republica; Datastream; Haver; and IMF staff calculations.

$1 /$ Combined permanent $1 / 4$ standard deviation shocks applied to interest rate, growth, and primary current account balance.

2/ 2009 data as of September, and includes US\$2 billion in issuances by public enterprises in July.

3/ Combined permanent $1 / 4$ standard deviation shocks applied to real interest rate, growth, and primary balance.

4/ One-time 10 percent of GDP increase in debt-creating flows. 
Figure 3. Colombia: External Debt Sustainability: Bound Tests 1/

(External debt in percent of GDP)
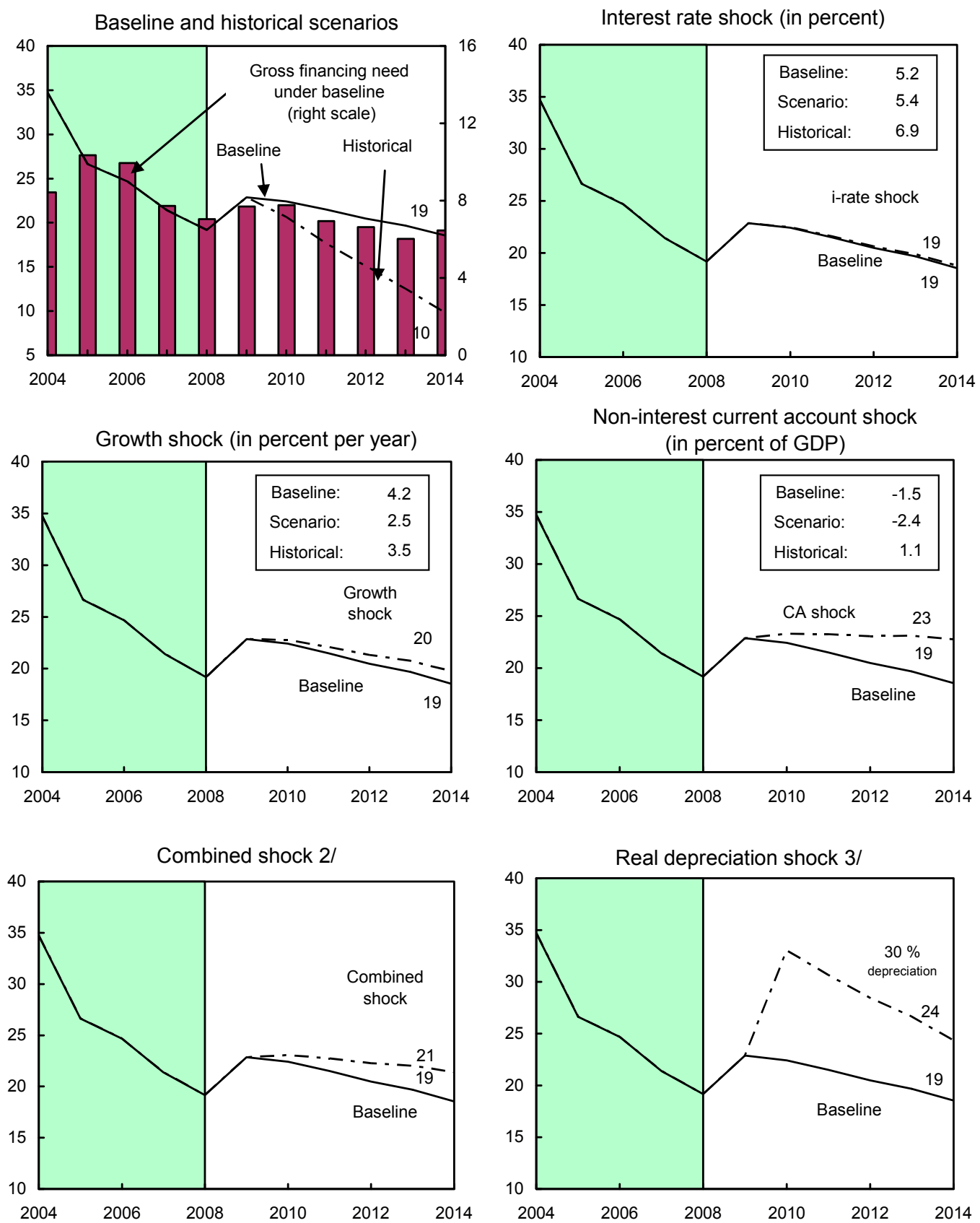

Sources: International Monetary Fund, Country desk data, and staff estimates.

1/ Shaded areas represent actual data. Individual shocks are permanent one-half standard deviation shocks. Figures in the boxes represent average projections for the respective variables in the baseline and scenario being presented. Ten-year historical average for the variable is also shown.

2/ Permanent 1/4 standard deviation shocks applied to real interest rate, growth rate, and current account balance.

3/ One-time real depreciation of 30 percent occurs in 2009. 
Figure 4. Colombia: Public Debt Sustainability: Bound Tests 1/

(Public debt in percent of GDP)
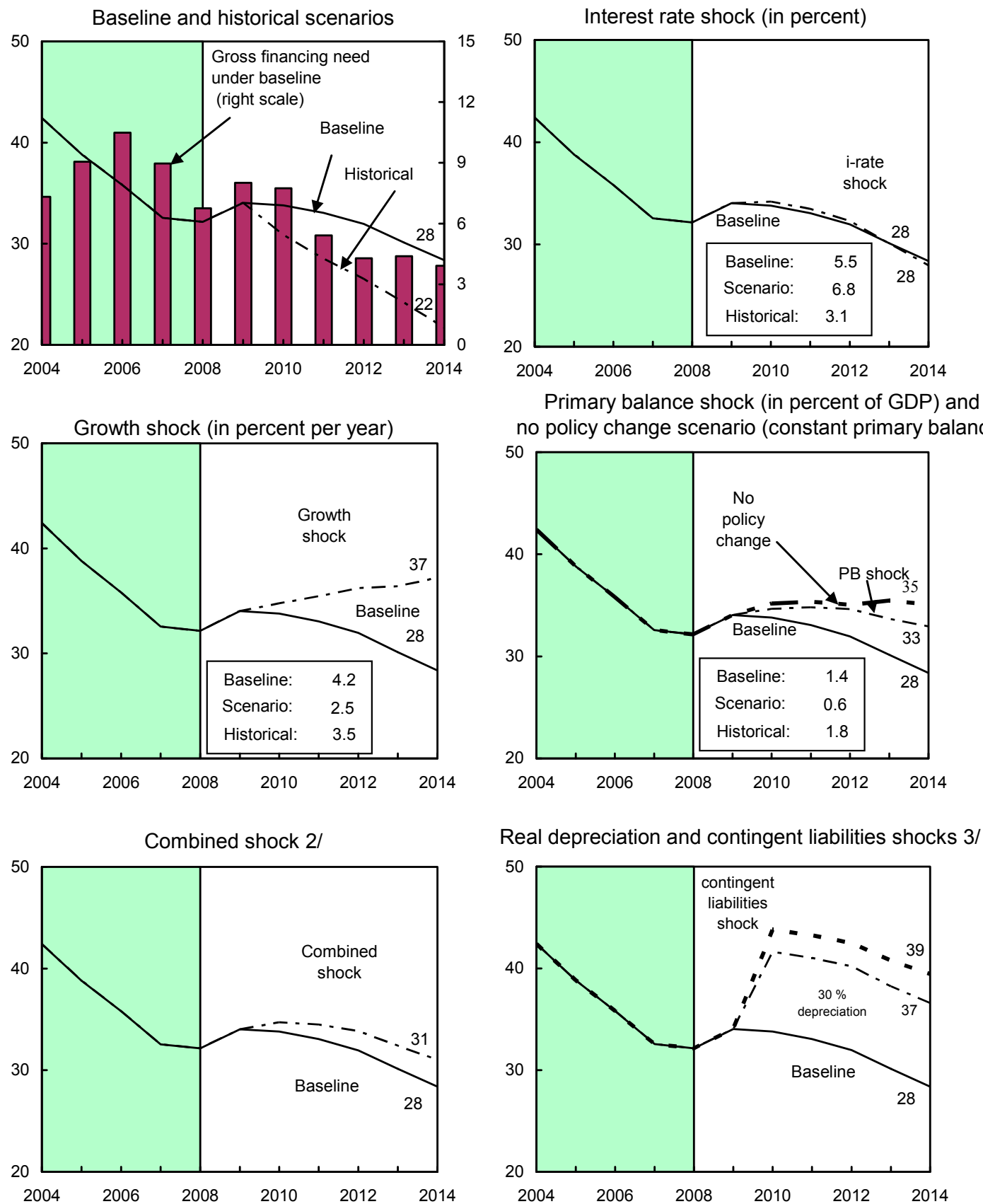

Real depreciation and contingent liabilities shocks 3/

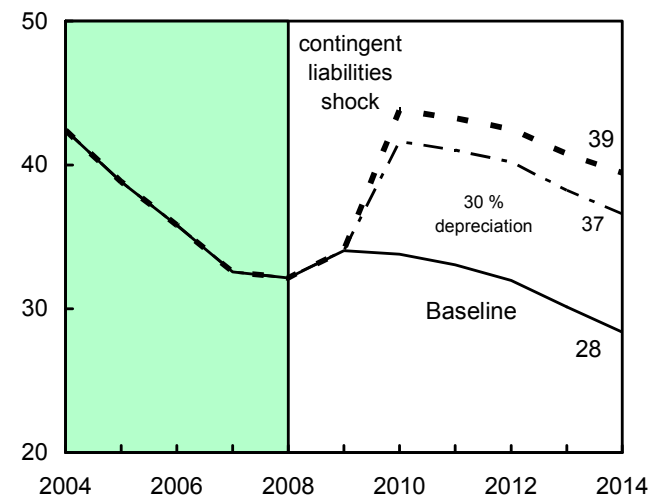

Sources: International Monetary Fund, country desk data, and staff estimates.

1/ Shaded areas represent actual data. Individual shocks are permanent one-half standard deviation shocks. Figures in the boxes represent average projections for the respective variables in the baseline and scenario being presented. Ten-year historical average for the variable is also shown.

2/ Permanent 1/4 standard deviation shocks applied to real interest rate, growth rate, and primary balance.

$3 /$ One-time real depreciation of 30 percent and 10 percent of GDP shock to contingent liabilities occur in 2009, with real depreciation defined as nominal depreciation (measured by percentage fall in dollar value of local currency) minus domestic inflation (based on GDP deflator). 
Table 1. Colombia: Selected Economic and Financial Indicators

Population (millions), 2008 GDP, 2008

per capita (US\$)

in billions of Col\$

in billions of US\$

Unemployment rate, July 2009 (percent)

Life expectancy at birth (years) (HDI), 2005

Under 5 mortality rate (per 1,000 live births), 2005

I. Social and Demographic Indicators

$\begin{array}{rlr}48.3 & \text { Physicians (per 100,000 people), 2000-2004 } & 135.0 \\ 4,986 & \text { Adult illiteracy rate (percent ages 15 and older), 2005 } & 7.2 \\ 479,619 & \text { Sustainable access to safe water, 2004 } & 93.0 \\ 240.8 & \quad \text { (percent of population) } & 58.6 \\ 12.6 & \text { Gini index, 2003 } & 25.3 \\ 72.3 & \text { Inequality (ratio of richest 20\% to poorest 20\%), 2003 } \\ 21.0 & \text { Poverty rate, 2006 } & 45.1 \\ & \text { Extreme poverty rate, 2006 }\end{array}$

II. Economic Indicators

\begin{tabular}{|c|c|c|c|c|c|c|}
\hline & \multirow[b]{2}{*}{2005} & \multirow[b]{2}{*}{2006} & \multirow[b]{2}{*}{2007} & \multirow[b]{2}{*}{2008} & \multicolumn{2}{|c|}{ Staff projections } \\
\hline & & & & & 2009 & 2010 \\
\hline \multicolumn{7}{|c|}{ (Percentage changes, unless otherwise indicated) } \\
\hline \multicolumn{7}{|l|}{ National income and prices } \\
\hline Real GDP & 5.7 & 6.9 & 7.5 & 2.4 & 0.2 & 2.5 \\
\hline GDP deflator & 6.1 & 6.8 & 4.8 & 8.4 & 3.1 & 4.3 \\
\hline Consumer prices (average) & 5.0 & 4.3 & 5.5 & 7.0 & 4.5 & 3.7 \\
\hline Consumer prices (end of period) & 4.9 & 4.5 & 5.7 & 7.7 & 3.5 & 3.6 \\
\hline \multicolumn{7}{|l|}{ External sector (on the basis of US\$) } \\
\hline Exports (f.o.b.) & 26.2 & 15.9 & 21.4 & 26.0 & -18.7 & 11.4 \\
\hline Imports (f.o.b.) & 26.8 & 23.5 & 25.4 & 20.5 & -13.3 & 11.7 \\
\hline Terms of trade (deterioration -) & 12.6 & 2.8 & 4.2 & 12.9 & -11.6 & -2.7 \\
\hline Real effective exchange rate (depreciation -) & 11.6 & -1.9 & 8.2 & -4.4 & $\ldots$ & $\ldots$ \\
\hline \multicolumn{7}{|l|}{ Central government } \\
\hline Revenue & 15.1 & 22.8 & 14.8 & 16.7 & 4.1 & -1.3 \\
\hline Expenditure & 10.4 & 16.9 & 9.9 & 13.5 & 14.5 & 2.2 \\
\hline \multicolumn{7}{|l|}{ Money and credit } \\
\hline Broad money & 17.6 & 18.0 & 17.4 & 18.5 & 13.4 & 11.3 \\
\hline Credit to the private sector $1 /$ & 11.3 & 38.5 & 23.5 & 15.9 & 6.0 & $\ldots$ \\
\hline \multicolumn{7}{|c|}{ Interest rate (90-day time deposits; percent per year) 2/ } \\
\hline Nominal & 6.3 & 6.8 & 9.2 & 9.8 & 4.5 & $\ldots$ \\
\hline \multirow[t]{2}{*}{ Real } & 1.4 & 2.3 & 3.5 & 2.1 & 1.3 & $\cdots$ \\
\hline & \multicolumn{6}{|c|}{ (In percent of GDP) } \\
\hline Central government balance & -4.0 & -3.4 & -2.7 & -2.3 & -4.1 & -4.5 \\
\hline Nonfinancial public sector balance & 0.0 & -1.0 & -0.8 & -0.3 & -3.0 & -3.1 \\
\hline NFPS primary balance & 3.4 & 2.9 & 3.2 & 3.2 & 0.5 & 0.5 \\
\hline Combined public sector balance & 0.0 & -0.7 & -0.7 & -0.1 & -3.1 & -3.0 \\
\hline Foreign financing & -1.4 & 0.3 & 0.9 & 0.0 & 3.0 & 1.0 \\
\hline Domestic financing $3 /$ & 1.4 & 0.4 & -0.3 & 0.1 & -0.2 & 1.2 \\
\hline Privatization & 0.0 & 0.0 & 0.0 & 0.1 & 0.2 & 0.8 \\
\hline Public debt & 38.8 & 35.8 & 32.6 & 32.2 & 34.0 & 33.8 \\
\hline Gross domestic investment & 21.6 & 24.3 & 24.3 & 24.7 & 22.6 & 23.2 \\
\hline Gross national savings & 20.3 & 22.5 & 21.5 & 22.0 & 19.7 & 20.0 \\
\hline Current account (deficit -) & -1.3 & -1.8 & -2.8 & -2.8 & -3.0 & -3.2 \\
\hline External debt & 26.6 & 24.7 & 21.4 & 19.2 & 22.9 & 22.4 \\
\hline Of which: public sector & 16.7 & 16.2 & 13.9 & 12.2 & 16.1 & 16.1 \\
\hline \multirow[t]{2}{*}{ NIR in percent of short-term debt } & 108.1 & 147.0 & 197.5 & 214.8 & 215.5 & 236.5 \\
\hline & \multicolumn{6}{|c|}{ (In percent of exports of goods, services, and income) } \\
\hline External debt service & 45.8 & 35.4 & 25.0 & 22.2 & 23.9 & 25.4 \\
\hline Of which: public sector & 31.0 & 20.0 & 14.4 & 12.5 & 11.0 & 13.8 \\
\hline Interest payments & 11.8 & 9.4 & 9.0 & 8.6 & 9.1 & 9.9 \\
\hline \multirow[t]{2}{*}{ Of which: public sector } & 8.7 & 6.4 & 6.2 & 6.2 & 6.2 & 7.4 \\
\hline & \multicolumn{6}{|c|}{ (In millions of U.S. dollars) } \\
\hline Overall balance of payments & 1,729 & 23 & 4,714 & 2,638 & 846 & 565 \\
\hline Exports (f.o.b.) & 21,729 & 25,181 & 30,577 & 38,531 & 31,327 & 34,888 \\
\hline Of which: Petroleum products & 5,559 & 6,328 & 7,318 & 12,204 & 8,593 & 10,272 \\
\hline Coffee & 1,471 & 1,461 & 1,714 & 1,883 & 1,837 & 1,791 \\
\hline Gross official reserves & 14,634 & 15,109 & 20,607 & 23,672 & 24,517 & 25,102 \\
\hline \multicolumn{7}{|l|}{ Gross official reserves (in months } \\
\hline of imports of goods and services) & 5.8 & 4.8 & 5.5 & 7.3 & 6.7 & 6.3 \\
\hline
\end{tabular}

Sources: Colombian authorities; UNDP Human Development Report 2007/08; World Development Indicators; and Fund staff estimates and projections.

1/ Data for 2009 refer to July.

2/ Data for 2009 refer to September.

3/ Includes the quasi-fiscal balance of Banco de la República, sales of assets, phone licenses, and statistical discrepancy. 
Table 2. Colombia: Summary Balance of Payments

\begin{tabular}{|c|c|c|c|c|c|c|c|c|c|c|}
\hline & \multirow[b]{2}{*}{2005} & \multirow[b]{2}{*}{2006} & \multirow[b]{2}{*}{2007} & \multirow[b]{2}{*}{2008} & \multicolumn{6}{|c|}{ Staff Projections } \\
\hline & & & & & 2009 & 2010 & 2011 & 2012 & 2013 & 2014 \\
\hline & \multicolumn{10}{|c|}{ (In millions of U.S. dollars) } \\
\hline Current account balance & $-1,882$ & $-2,983$ & $-5,819$ & $-6,713$ & $-6,762$ & $-7,850$ & $-7,679$ & $-6,504$ & $-6,327$ & $-6,846$ \\
\hline Trade balance & 1,595 & 322 & -596 & 976 & $-1,236$ & $-1,485$ & $-1,966$ & -972 & -618 & -855 \\
\hline Exports, f.o.b. & 21,729 & 25,181 & 30,577 & 38,531 & 31,327 & 34,888 & 37,839 & 41,965 & 45,519 & 48,896 \\
\hline Coffee & 1,471 & 1,461 & 1,714 & 1,883 & 1,837 & 1,791 & 1,840 & 2,068 & 2,398 & 2,470 \\
\hline Petroleum products & 5,559 & 6,328 & 7,318 & 12,204 & 8,593 & 10,272 & 11,823 & 12,166 & 12,965 & 13,900 \\
\hline Non-traditional & 9,863 & 11,749 & 15,174 & 17,101 & 14,697 & 16,011 & 16,660 & 19,498 & 21,215 & 22,892 \\
\hline Other & 4,836 & 5,642 & 6,370 & 7,344 & 6,199 & 6,814 & 7,516 & 8,232 & 8,941 & 9,634 \\
\hline Imports, f.o.b. & 20,134 & 24,859 & 31,173 & 37,556 & 32,563 & 36,373 & 39,805 & 42,937 & 46,137 & 49,751 \\
\hline Services (net) & $-2,102$ & $-2,119$ & $-2,607$ & $-3,140$ & $-2,278$ & $-3,109$ & $-3,339$ & $-3,560$ & $-3,806$ & $-4,076$ \\
\hline Income (net) & $-5,456$ & $-5,929$ & $-7,847$ & $-10,063$ & $-7,963$ & $-8,098$ & $-7,459$ & $-7,375$ & $-7,666$ & $-8,061$ \\
\hline Interest (net) & $-2,051$ & $-1,693$ & $-1,732$ & $-2,092$ & $-2,560$ & $-2,924$ & $-2,009$ & $-1,617$ & $-1,619$ & $-1,647$ \\
\hline Ot which: public sector & $-1,587$ & $-1,208$ & $-1,279$ & $-1,561$ & $-1,696$ & $-2,235$ & $-1,903$ & $-1,734$ & $-1,778$ & $-1,815$ \\
\hline Other Income (net) & $-3,405$ & $-4,236$ & $-6,115$ & $-7,970$ & $-5,404$ & $-5,174$ & $-5,450$ & $-5,759$ & $-6,046$ & $-6,414$ \\
\hline Current transfers (net) & 4,082 & 4,743 & 5,231 & 5,514 & 4,716 & 4,841 & 5,085 & 5,403 & 5,763 & 6,146 \\
\hline Financial account balance & 3,236 & 2,890 & 10,345 & 9,506 & 7,616 & 8,416 & 8,218 & 7,010 & 6,837 & 7,343 \\
\hline Public sector (net) & $-2,974$ & -432 & 2,198 & -309 & 7,507 & 2,629 & 1,340 & 1,315 & 1,330 & 1,338 \\
\hline Nonfinancial public sector & $-2,129$ & 722 & 1,928 & -95 & 6,376 & 2,411 & 1,014 & 1,201 & 1,221 & 1,250 \\
\hline Medium- and long-term (net) & $-1,189$ & 2,085 & 1,298 & 998 & 6,273 & 2,432 & 438 & 729 & 753 & 279 \\
\hline Disbursements & 4,312 & 5,869 & 4,096 & 3,246 & 7,859 & 4,781 & 2,553 & 3,606 & 3,465 & 4,371 \\
\hline Amortization & 5,501 & 3,784 & 2,798 & 2,248 & 1,586 & 2,349 & 2,115 & 2,877 & 2,712 & 4,092 \\
\hline Other long-term flows & -47 & -46 & -19 & 0 & -1 & -1 & -1 & -1 & -1 & -1 \\
\hline Short term $1 /$ & -893 & $-1,317$ & 649 & $-1,093$ & 105 & -20 & 577 & 474 & 469 & 972 \\
\hline Of which: change in public assets & -849 & $-1,598$ & -662 & -50 & -14 & -20 & 577 & 474 & 469 & 972 \\
\hline Financial public sector & -845 & $-1,154$ & 270 & -215 & 1,131 & 217 & 326 & 114 & 108 & 88 \\
\hline Private sector (net) & 6,210 & 3,322 & 8,147 & 9,815 & 109 & 5,787 & 6,878 & 5,695 & 5,508 & 6,004 \\
\hline Nonfinancial private sector (net) & 6,122 & 3,380 & 7,916 & 8,819 & 2,105 & 6,290 & 7,304 & 6,222 & 6,083 & 6,577 \\
\hline Direct investment & 5,590 & 5,558 & 8,136 & 8,346 & 5,432 & 6,514 & 6,463 & 6,400 & 6,364 & 6,292 \\
\hline Direct investment abroad & 4,662 & 1,098 & 913 & 2,254 & 3,150 & 2,203 & 2,378 & 2,599 & 2,811 & 3,061 \\
\hline Direct investment in Colombia & 10,252 & 6,656 & 9,049 & 10,600 & 8,582 & 8,717 & 8,841 & 8,998 & 9,174 & 9,354 \\
\hline Leasing finance & 116 & 62 & 116 & 277 & -197 & 150 & 151 & 300 & 371 & 288 \\
\hline Disbursements & 378 & 501 & 656 & 1,004 & 633 & 642 & 700 & 736 & 778 & 838 \\
\hline Amortization & 262 & 439 & 540 & 726 & 830 & 492 & 548 & 436 & 406 & 550 \\
\hline Long-term loans & -436 & -79 & 951 & 394 & -481 & -268 & -197 & -256 & -206 & -243 \\
\hline Disbursements & 1,948 & 2,837 & 3,031 & 2,131 & 1,923 & 2,408 & 1,775 & 2,306 & 1,854 & 2,191 \\
\hline Amortization & 2,385 & 2,916 & 2,080 & 1,736 & 2,404 & 2,675 & 1,972 & 2,562 & 2,060 & 2,435 \\
\hline Short term $2 /$ & 853 & $-2,161$ & $-1,288$ & -198 & $-2,650$ & -106 & 888 & -222 & -446 & 240 \\
\hline Financial private sector (net) & 88 & -57 & 231 & 996 & $-1,996$ & -503 & -426 & -527 & -575 & -572 \\
\hline Net errors and omissions & 374 & 115 & 186 & -160 & 0 & 0 & 0 & 0 & 0 & 0 \\
\hline Changes in GIR 3/ 4/ & 1,729 & 23 & 4,714 & 2,638 & 846 & 565 & 539 & 506 & 511 & 496 \\
\hline \multicolumn{11}{|l|}{ Memorandum Items: } \\
\hline Current account balance (in percent of GDP) & -1.3 & -1.8 & -2.8 & -2.8 & -3.0 & -3.2 & -2.9 & -2.3 & -2.1 & -2.1 \\
\hline Oil Price (Colombian mix) & 49.8 & 58.3 & 66.2 & 90.2 & 57.2 & 71.1 & 73.9 & 75.3 & 77.1 & 78.8 \\
\hline Gross international reserves (in US\$ billion) & 14.6 & 15.1 & 20.6 & 23.7 & 24.5 & 25.1 & 25.7 & 26.2 & 26.8 & 27.3 \\
\hline \multicolumn{11}{|l|}{ Gross international reserves (months of imports } \\
\hline of $\mathrm{G} \& S)$ & 5.8 & 4.8 & 5.5 & 7.3 & 6.7 & 6.3 & 6.0 & 5.7 & 5.4 & 5.4 \\
\hline
\end{tabular}

Sources: Banco de la República; and Fund staff estimates and projections.

$1 /$ Includes movements of short-term assets owned by the public sector abroad.

2/ Includes net portfolio investment.

$3 /$ Does not include valuation changes of reserves denominated in other currencies than U.S. dollars.

4/ Figures for 2009 include SDR allocation to Colombia amounting to US\$972 million. 
Table 3. Colombia: External Financing Requirements and Sources (In millions of U.S. dollars)

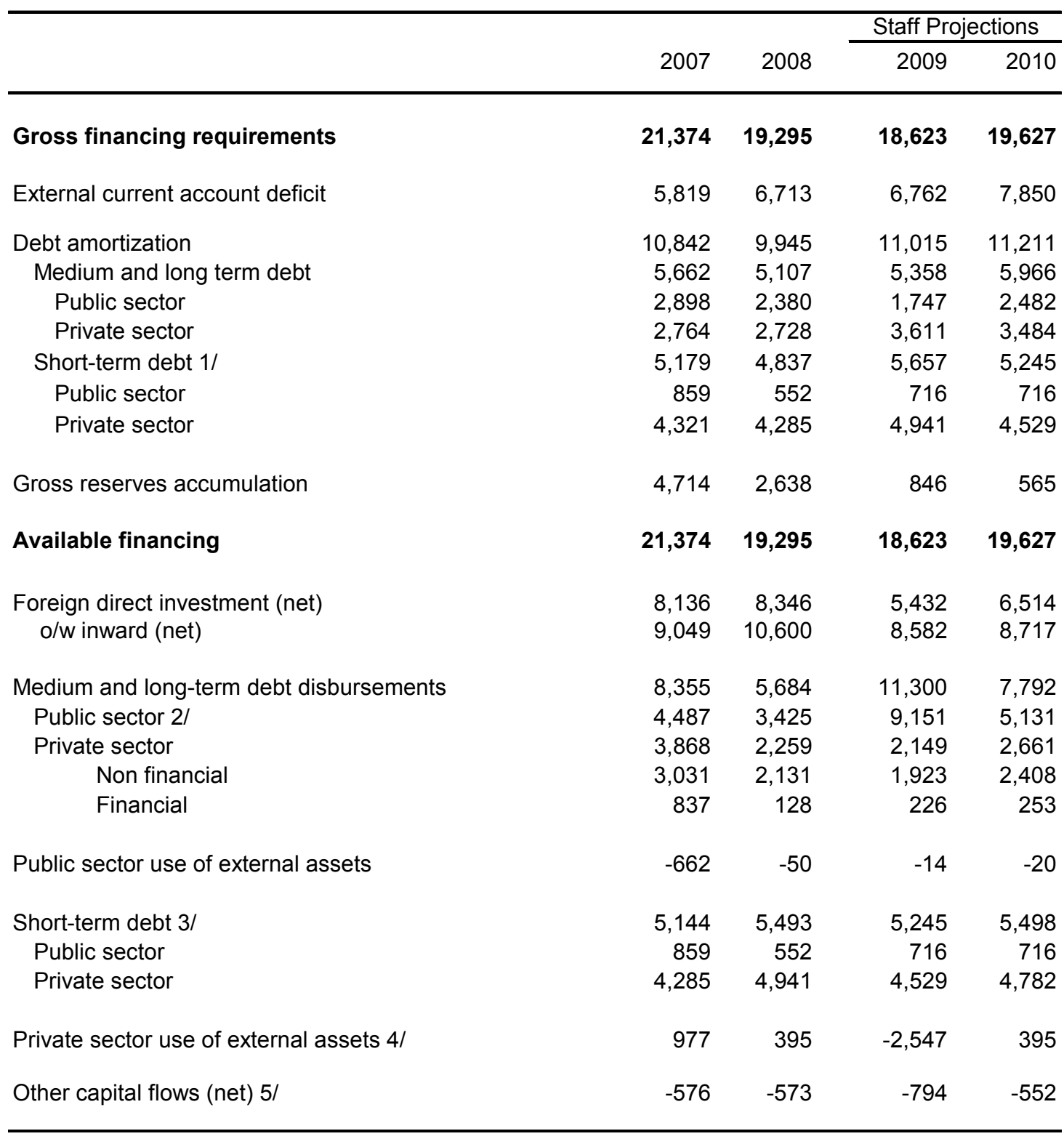

Sources: Banco de la República and Fund staff estimates.

$1 /$ Original maturity of less than 1 year. Stock at the end of the previous period.

2/ Including financial public sector. Projection for 2009 includes SDR allocation to Colombia (US $\$ 972$ million).

$3 /$ Original maturity of less than 1 year. Stock at the end of the current period.

4/ Includes pension funds and other portfolio flows

5 / Includes all other net financial flows, and errors and omissions. 
Table 4. Colombia: Operations of the Combined Public Sector 1/ (In percent of GDP)

\begin{tabular}{|c|c|c|c|c|c|c|c|c|c|c|}
\hline & \multirow[b]{2}{*}{2005} & \multirow[b]{2}{*}{2006} & \multirow[b]{2}{*}{2007} & \multirow[b]{2}{*}{2008} & \multicolumn{6}{|c|}{ Staff Projections } \\
\hline & & & & & 2009 & 2010 & 2011 & 2012 & 2013 & 2014 \\
\hline Total revenue & 26.1 & 27.3 & 27.1 & 26.6 & 26.4 & 25.6 & 26.2 & 26.4 & 26.4 & 26.2 \\
\hline Tax revenue & 14.9 & 19.3 & 19.3 & 19.3 & 18.9 & 18.6 & 19.0 & 19.1 & 19.2 & 19.1 \\
\hline Nontax revenue & 11.1 & 8.1 & 7.8 & 7.3 & 7.4 & 7.0 & 7.2 & 7.3 & 7.3 & 7.1 \\
\hline Financial income & 1.3 & 1.2 & 1.4 & 1.3 & 1.3 & 1.3 & 1.3 & 1.3 & 1.3 & 1.3 \\
\hline Operating surplus of public enterprises & 3.3 & 3.6 & 3.2 & 0.4 & 0.4 & 0.4 & 0.4 & 0.4 & 0.4 & 0.4 \\
\hline Of which: Ecopetrol & 3.1 & 3.4 & 3.0 & 0.0 & 0.0 & 0.0 & 0.0 & 0.0 & 0.0 & 0.0 \\
\hline Other & 6.6 & 3.3 & 3.2 & 5.6 & 5.7 & 5.2 & 5.5 & 5.6 & 5.5 & 5.4 \\
\hline Total expenditure and net lending $2 /$ & 26.2 & 28.2 & 28.2 & 26.5 & 29.4 & 28.7 & 28.3 & 28.1 & 27.7 & 27.4 \\
\hline Current expenditure & 21.2 & 22.6 & 21.8 & 21.5 & 23.4 & 22.9 & 22.5 & 22.2 & 21.9 & 21.5 \\
\hline Wages and salaries & 5.7 & 5.8 & 5.6 & 5.6 & 5.9 & 6.0 & 5.9 & 5.7 & 5.6 & 5.5 \\
\hline Goods and services & 3.6 & 3.6 & 3.6 & 3.4 & 3.3 & 3.4 & 3.3 & 3.2 & 3.2 & 3.1 \\
\hline Interest & 3.4 & 3.9 & 4.0 & 3.5 & 3.5 & 3.6 & 3.2 & 3.2 & 3.2 & 3.2 \\
\hline External & 1.4 & 1.2 & 1.0 & 0.8 & 0.9 & 1.0 & 0.8 & 0.7 & 0.7 & 0.6 \\
\hline Domestic & 2.0 & 2.7 & 3.1 & 2.7 & 2.6 & 2.6 & 2.4 & 2.5 & 2.6 & 2.5 \\
\hline Transfers to private sector & 6.7 & 7.3 & 7.2 & 7.5 & 9.2 & 8.4 & 8.6 & 8.6 & 8.6 & 8.4 \\
\hline Of which: from social security & 5.8 & 6.4 & 6.4 & 6.7 & 7.5 & 7.6 & 7.5 & 7.3 & 7.2 & 7.1 \\
\hline Other $3 /$ & 1.8 & 2.0 & 1.3 & 1.5 & 1.5 & 1.5 & 1.5 & 1.5 & 1.3 & 1.3 \\
\hline Capital expenditure & 5.0 & 5.5 & 6.4 & 5.1 & 6.0 & 5.8 & 5.8 & 5.8 & 5.8 & 5.8 \\
\hline Statistical discrepancy & 0.1 & -0.2 & 0.2 & -0.3 & 0.0 & 0.0 & 0.0 & 0.0 & 0.0 & 0.0 \\
\hline Nonfinancial public sector balance & 0.0 & -1.0 & -0.8 & -0.3 & -3.0 & -3.1 & -2.1 & -1.6 & -1.3 & -1.2 \\
\hline Quasi-fiscal balance (BR cash profits) & 0.2 & 0.4 & 0.4 & 0.3 & 0.0 & 0.1 & 0.1 & 0.2 & 0.2 & 0.3 \\
\hline Fogafin balance & 0.2 & 0.2 & 0.1 & 0.1 & 0.2 & 0.2 & 0.1 & 0.2 & 0.2 & 0.2 \\
\hline Net cost of financial restructuring 4 / & -0.4 & -0.3 & -0.3 & -0.3 & -0.2 & -0.1 & 0.0 & 0.0 & 0.0 & 0.0 \\
\hline Combined public sector balance & 0.0 & -0.7 & -0.7 & -0.1 & -3.1 & -3.0 & -1.9 & -1.3 & -0.9 & -0.7 \\
\hline \multicolumn{11}{|l|}{ Memorandum items: } \\
\hline NFPS primary balance & 3.4 & 2.9 & 3.2 & 3.2 & 0.5 & 0.5 & 1.1 & 1.6 & 2.0 & 2.0 \\
\hline NFPS primary structural balance $5 /$ & 3.2 & 2.9 & 2.2 & 2.1 & 1.6 & 1.7 & 2.1 & 2.0 & 2.0 & 2.0 \\
\hline
\end{tabular}

Sources: Ministry of Finance; Banco de la República; and Fund staff estimates and projections.

1/ Combined public sector includes the central, regional and local governments, social security, and public sector enterprises. Figures for 2008 and projections reflect exclusion of Ecopetrol operations and privatization of health care, which reduces revenue and spending by about 2 percent of GDP and 1.5 percent of GDP, respectively, in 2008.

2/ Expenditure reported on commitments basis.

$3 /$ Includes adjustments to put spending on commitment basis and the change in unpaid bills of selected nonfinancial public enterprises.

4/ Interest payments on public banks restructuring bonds and mortgage debt relief related costs.

$5 /$ Removes cyclical component by adjusting for the output gap and commodity price expectations. 
Table 5. Colombia: Financial Soundness Indicators

Total Banking System

(In percent, unless otherwise indicated; end-of-period values)

\begin{tabular}{|c|c|c|c|c|c|c|c|c|}
\hline & 2005 & 2006 & 2007 & Apr-08 & Aug-08 & 2008 & Apr-09 & Aug-09 \\
\hline \multicolumn{9}{|l|}{ Capital Adequacy } \\
\hline Regulatory capital to risk-weighted assets & 14.7 & 13.1 & 13.6 & 14.0 & 14.3 & 13.4 & 14.8 & 15.3 \\
\hline $\begin{array}{l}\text { Regulatory Tier } 1 \text { capital to risk-weighted } \\
\text { assets }\end{array}$ & 10.4 & 9.7 & 10.5 & 11.1 & 11.5 & 10.7 & 11.7 & 12.3 \\
\hline Capital (net worth) to assets & 12.3 & 12.0 & 12.1 & 11.7 & 12.4 & 12.2 & 12.5 & 13.5 \\
\hline \multicolumn{9}{|l|}{ Asset Quality and Distribution } \\
\hline Nonperforming loans to gross loans & 2.7 & 2.6 & 3.3 & 3.9 & 4.1 & 4.0 & 4.7 & 4.7 \\
\hline Provisions to nonperforming loans & 166.9 & 153.6 & 132.6 & 116.3 & 115.8 & 120.5 & 113.7 & 117.0 \\
\hline Government securities to assets & 24.9 & 15.5 & 12.2 & 12.7 & 12.4 & 13.5 & 13.9 & 14.3 \\
\hline Gross loans to assets & 52.3 & 60.6 & 64.3 & 64.3 & 65.7 & 64.6 & 62.1 & 61.3 \\
\hline \multicolumn{9}{|l|}{ Earnings and Profitability } \\
\hline ROAA & 2.7 & 2.5 & 2.4 & 2.7 & 2.6 & 2.4 & 2.8 & 2.7 \\
\hline ROAE & 22.1 & 20.2 & 19.5 & 23.1 & 21.5 & 20.0 & 22.4 & 20.7 \\
\hline Interest margin to gross income & 40.2 & 46.6 & 54.4 & 53.4 & 54.5 & 54.3 & 50.9 & 53.4 \\
\hline Interest income to gross income & 42.8 & 39.6 & 44.9 & 51.0 & 49.9 & 48.5 & 54.5 & 53.4 \\
\hline Operating expenses to gross income & 57.2 & 60.4 & 55.1 & 49.0 & 50.1 & 51.5 & 45.5 & 46.6 \\
\hline \multicolumn{9}{|l|}{ Liquidity } \\
\hline Liquid assets to total assets & 20.8 & 14.0 & 13.0 & 13.6 & 12.4 & 13.9 & 16.0 & 16.6 \\
\hline Liquid assets to short-term liabilities & 31.3 & 20.7 & 19.3 & 20.4 & 18.7 & 20.5 & 24.6 & 25.2 \\
\hline Loan to deposit ratio $1 /$ & 79.0 & 89.7 & 95.8 & 96.5 & 98.9 & 95.3 & 95.1 & 92.8 \\
\hline
\end{tabular}

Sources: Superintendencia Financiera; and Creditedge (Moody's-KMV).

1/ The denominator includes certificates of deposits. 
Table 6. Colombia: Indicators of Fund Credit, 2008-14

\begin{tabular}{|c|c|c|c|c|c|c|c|}
\hline & \multirow[b]{2}{*}{2008} & \multicolumn{6}{|c|}{ Staff Projections } \\
\hline & & 2009 & 2010 & 2011 & 2012 & 2013 & 2014 \\
\hline \multicolumn{8}{|l|}{ Stocks from prospective drawings $1 /$} \\
\hline Fund credit in millions SDR & & 6,966 & 6,966 & 6,966 & 5,225 & 1,742 & 0 \\
\hline In percent of quota & & 900 & 900 & 900 & 675 & 225 & 0 \\
\hline In percent of GDP & & 4.8 & 4.5 & 4.2 & 3.0 & 0.9 & 0.0 \\
\hline In percent of exports of goods and services & & 31.1 & 28.2 & 26.0 & 17.7 & 5.5 & 0.0 \\
\hline In percent of gross reserves $2 /$ & & 28.0 & 43.4 & 42.5 & 31.3 & 10.2 & 0.0 \\
\hline \multicolumn{8}{|l|}{ Flows from prospective drawings $3 /$} \\
\hline Amortization & & 0 & 0 & 0 & 1,742 & 3,483 & 1,742 \\
\hline GRA Charges & & 43.8 & 92.0 & 92.0 & 89.4 & 52.9 & 9.5 \\
\hline Level Based Surcharge & & 23.4 & 92.9 & 92.9 & 98.7 & 50.6 & 0.2 \\
\hline Service Charge & & 34.8 & 0.0 & 0.0 & 0.0 & 0.0 & 0.0 \\
\hline Debt service due on GRA credit (millions SDR) & & 102 & 185 & 185 & 1,930 & 3,587 & 1,751 \\
\hline In percent of quota & & 13.2 & 23.9 & 23.9 & 249.3 & 463.4 & 226.3 \\
\hline In percent of GDP & & 0.1 & 0.1 & 0.1 & 1.1 & 1.9 & 0.9 \\
\hline In percent of exports of goods and services & & 0.5 & 0.7 & 0.7 & 6.5 & 11.2 & 5.1 \\
\hline In percent of gross reserves 2 / & & 0.7 & 1.2 & 1.1 & 11.6 & 21.1 & 10.1 \\
\hline \multicolumn{8}{|l|}{ Memorandum Item: } \\
\hline Total External Debt, assuming full drawing (\% of GDP) & 19.2 & 27.7 & 26.9 & 25.7 & 23.4 & 20.6 & 18.5 \\
\hline Total Debt Service, assuming full drawing (\% of GDP) & 3.5 & 3.9 & 4.1 & 3.4 & 4.5 & 4.9 & 4.3 \\
\hline
\end{tabular}

Sources: IMF Finance Department; Colombian authorities, and Fund staff estimates.

1/ End of period. Assumes full drawings under the FCL upon approval. The Colombian authorities have expressed their intention to treat the arrangement as precautionary. At an SDR/US\$ rate of 0.630475 as of October 7, 2009.

2/ Excludes IMF purchases.

3/ Based on the rate of charge as of April 23, 2009. Includes surcharges under the system currently in force and service charges. 
Table 7. Colombia: External Debt Sustainability Framework, 2004-2014

(In percent of GDP, unless otherwise indicated)

\begin{tabular}{|c|c|c|c|c|c|c|c|c|c|c|c|c|}
\hline & \multicolumn{5}{|c|}{ Actual } & \multicolumn{6}{|c|}{ Staff Projections 1/ } & \multirow{3}{*}{$\begin{array}{c}\text { Debt-stabilizing } \\
\text { non-interest } \\
\text { current account 7/ } \\
-2.8\end{array}$} \\
\hline & 2004 & 2005 & 2006 & 2007 & 2008 & 2009 & 2010 & 2011 & 2012 & 2013 & 2014 & \\
\hline Baseline: External debt & 34.7 & 26.6 & 24.7 & 21.4 & 19.2 & 22.9 & 22.4 & 21.5 & 20.5 & 19.7 & 18.5 & \\
\hline Change in external debt & -6.8 & -8.1 & -2.0 & -3.3 & -2.2 & 3.7 & -0.4 & -0.9 & -1.0 & -0.8 & -1.1 & \\
\hline Identified external debt-creating flows $(4+8+9)$ & -9.8 & -9.9 & -4.5 & -6.5 & -3.6 & 0.5 & 0.0 & -0.4 & -1.0 & -1.0 & -1.0 & \\
\hline Current account deficit, excluding interest payments & -1.4 & -0.6 & 0.1 & 1.3 & 1.6 & 1.6 & 1.8 & 1.9 & 1.4 & 1.2 & 1.2 & \\
\hline Deficit in balance of goods and services & 0.3 & 0.4 & 1.1 & 1.5 & 0.9 & 1.5 & 1.9 & 2.0 & 1.6 & 1.5 & 1.5 & \\
\hline Exports & 17.1 & 16.9 & 17.6 & 16.4 & 17.7 & 15.5 & 16.0 & 16.3 & 16.8 & 17.0 & 17.0 & \\
\hline Imports & 17.4 & 17.2 & 18.7 & 18.0 & 18.6 & 17.1 & 17.9 & 18.3 & 18.4 & 18.5 & 18.5 & \\
\hline Net non-debt creating capital inflows (negative) & -2.6 & -3.9 & -3.4 & -3.9 & -3.5 & -2.4 & -2.7 & -2.5 & -2.3 & -2.1 & -2.3 & \\
\hline Automatic debt dynamics $2 /$ & -5.8 & -5.5 & -1.2 & -3.9 & -1.7 & 1.3 & 0.8 & 0.2 & 0.0 & 0.0 & 0.1 & \\
\hline Contribution from nominal interest rate & 2.2 & 1.9 & 1.7 & 1.5 & 1.2 & 1.4 & 1.4 & 1.1 & 1.0 & 0.9 & 0.9 & \\
\hline Contribution from real GDP growth & -1.6 & -1.6 & -1.6 & -1.5 & -0.4 & -0.1 & -0.5 & -0.8 & -1.0 & -1.0 & -0.8 & \\
\hline Contribution from price and exchange rate changes $3 /$ & -6.5 & -5.8 & -1.3 & -3.9 & -2.5 & & $\ldots$ & & & $\cdots$ & & \\
\hline Residual, incl. change in gross foreign assets (2-3) 4 / & 3.0 & 1.9 & 2.6 & 3.2 & 1.4 & 3.2 & -0.4 & -0.5 & 0.0 & 0.2 & -0.2 & \\
\hline External debt-to-exports ratio (in percent) & 202.8 & 157.9 & 140.4 & 130.1 & 108.4 & 147.2 & 140.1 & 132.2 & 122.2 & 115.6 & 109.4 & \\
\hline Gross external financing need (in billions of US dollars) 5 l & 9.6 & 15.0 & 16.2 & 16.1 & 17.0 & 17.6 & 19.0 & 18.1 & 18.5 & 17.9 & 20.7 & \\
\hline in percent of GDP & 8.4 & 10.3 & 10.0 & 7.7 & 7.0 & 7.7 & 7.8 & 6.9 & 6.6 & 6.0 & 6.5 & \\
\hline Scenario with key variables at their historical averages 6 / & & & & & & 22.9 & 20.6 & 17.7 & 15.1 & 12.5 & 9.8 & -2.2 \\
\hline \multicolumn{13}{|l|}{ Key Macroeconomic Assumptions Underlying Baseline } \\
\hline Real GDP growth (in percent) & 4.7 & 5.7 & 6.9 & 7.5 & 2.4 & 0.2 & 2.5 & 4.0 & 5.0 & 5.0 & 4.5 & \\
\hline GDP deflator in US dollars (change in percent) & 18.5 & 20.2 & 5.1 & 19.0 & 13.0 & -5.3 & 4.7 & 2.2 & 2.0 & 1.4 & 2.9 & \\
\hline Nominal external interest rate (in percent) & 6.7 & 7.0 & 7.2 & 7.6 & 6.5 & 6.9 & 6.4 & 5.1 & 4.8 & 4.8 & 4.8 & \\
\hline Growth of exports (US dollar terms, in percent) & 23.8 & 25.2 & 17.1 & 19.8 & 24.5 & -16.6 & 10.5 & 8.1 & 10.3 & 8.1 & 7.2 & \\
\hline Growth of imports (US dollar terms, in percent) & 19.2 & 25.7 & 21.9 & 23.3 & 19.6 & -12.8 & 12.3 & 8.8 & 7.6 & 7.2 & 7.5 & \\
\hline Current account balance, excluding interest payments & 1.4 & 0.6 & -0.1 & -1.3 & -1.6 & -1.6 & -1.8 & -1.9 & -1.4 & -1.2 & -1.2 & \\
\hline Net non-debt creating capital inflows & 2.6 & 3.9 & 3.4 & 3.9 & 3.5 & 2.4 & 2.7 & 2.5 & 2.3 & 2.1 & 2.3 & \\
\hline
\end{tabular}

Source: IMF staff estimates.

1/ Does not assume any drawings under the Flexible Credit Line arrangement.
$2 /$ Derived as $[r-g-r(1+g)+$ ea $(1+r)](1+g+r+g r)$ times previous period debt stock, with $r=$ nominal effective interest rate on external debt; $r=$ change in domestic GDP deflator in US dollar terms, $g=$ real GDP growth rate, $e=$ nominal 2/ Derived as $[r-g-r(1+g)+$ ea $(1+r)](1+g+r+g r)$ times previous period debt stock, with $r=$ nom donciation (increase in dollar value of domestic currency), and $a=$ share of domestic-currency deninated debt in total external debt.

$3 /$ The contribution from price and exchange rate changes is defined as $[-r(1+g)+e a(1+r)] /(1+g+r+g r)$ times previous period debt stock. $r$ increases with an appreciating domestic currency $(e>0)$ and rising inflation $($ based on GDP deflator). $4 /$ For projection, line includes the impact of price and exchange rate changes.

5/ Defined as current account deficit, plus amortization on medium- and long-term debt, plus short-term debt at end of previous period.
$6 /$ The key variables include real GDP growth- nominal interest rate; dollar deflator growth; and both non-interest current account and non

The key variables include real GDP growh, nominal interest rate, dollar deflator growh, and both nonimlest curent accoun and nor

feflat growth, and non-debt inflows in percent of GDP) remain at

Their levels of the last projection year. 
Table 8. Colombia: Public Sector Debt Sustainability Framework, 2004-2014 (In percent of GDP, unless otherwise indicated)

\begin{tabular}{|c|c|c|c|c|c|c|c|c|c|c|c|c|}
\hline & \multicolumn{5}{|c|}{ Actual } & \multicolumn{6}{|c|}{ Staff Projections $1 /$} & \multirow{4}{*}{$\begin{array}{c}\text { Debt-stabilizing } \\
\text { primary } \\
\text { balance 11/ } \\
1.1\end{array}$} \\
\hline & 2004 & 2005 & 2006 & 2007 & 2008 & 2009 & 2010 & 2011 & 2012 & 2013 & 2014 & \\
\hline & & & & & & & & & & & & \\
\hline Baseline: Public sector debt 2 / & 42.4 & 38.8 & 35.8 & 32.6 & 32.2 & 34.0 & 33.8 & 33.1 & 32.0 & 30.1 & 28.4 & \\
\hline $\mathrm{o} / \mathrm{w}$ foreign-currency denominated & 22.7 & 16.7 & 16.2 & 13.9 & 12.2 & 16.1 & 16.1 & 15.4 & 14.7 & 14.1 & 13.2 & \\
\hline Change in public sector debt & -3.8 & -3.6 & -3.0 & -3.2 & -0.4 & 1.9 & -0.2 & -0.7 & -1.1 & -1.8 & -1.7 & \\
\hline Identified debt-creating flows $(4+7+12)$ & -7.9 & -5.4 & -4.3 & -4.5 & -1.9 & 1.8 & 0.1 & -0.4 & -1.2 & -1.5 & -1.3 & \\
\hline Primary deficit & -3.0 & -3.2 & -3.0 & -3.0 & -3.6 & -0.5 & -0.5 & -1.1 & -1.6 & -2.0 & -2.0 & \\
\hline Revenue and grants & 25.9 & 26.1 & 27.3 & 27.1 & 26.6 & 26.4 & 25.6 & 26.2 & 26.4 & 26.4 & 26.2 & \\
\hline Primary (noninterest) expenditure & 22.9 & 22.8 & 24.3 & 24.1 & 23.0 & 25.9 & 25.1 & 25.1 & 24.8 & 24.5 & 24.2 & \\
\hline Automatic debt dynamics $3 /$ & -4.9 & -2.2 & -1.3 & -1.5 & 1.8 & 2.5 & 1.4 & 0.7 & 0.4 & 0.5 & 0.7 & \\
\hline Contribution from interest rate/growth differential $4 /$ & -1.4 & -1.2 & -1.0 & 0.0 & 0.3 & 2.5 & 1.4 & 0.7 & 0.4 & 0.5 & 0.7 & \\
\hline Of which contribution from real interest rate & 0.5 & 0.9 & 1.4 & 2.4 & 1.0 & 2.5 & 2.2 & 2.0 & 1.9 & 2.0 & 2.0 & \\
\hline Of which contribution from real GDP growth & -1.9 & -2.2 & -2.4 & -2.4 & -0.7 & -0.1 & -0.8 & -1.3 & -1.5 & -1.5 & -1.2 & \\
\hline Contribution from exchange rate depreciation $5 /$ & -3.5 & -1.0 & -0.3 & -1.5 & 1.6 & & & & & . & $\ldots$ & \\
\hline Other identified debt-creating flows & 0.0 & 0.0 & 0.0 & 0.0 & -0.1 & -0.2 & -0.8 & 0.0 & 0.0 & 0.0 & 0.0 & \\
\hline Privatization receipts (negative) & 0.0 & 0.0 & 0.0 & 0.0 & -0.1 & -0.2 & -0.8 & 0.0 & 0.0 & 0.0 & 0.0 & \\
\hline Recognition of implicit or contingent liabilities & 0.0 & 0.0 & 0.0 & 0.0 & 0.0 & 0.0 & 0.0 & 0.0 & 0.0 & 0.0 & 0.0 & \\
\hline Other (specify, e.g. bank recapitalization) & 0.0 & 0.0 & 0.0 & 0.0 & 0.0 & 0.0 & 0.0 & 0.0 & 0.0 & 0.0 & 0.0 & \\
\hline Residual, including asset changes (2-3) 6/ & 4.1 & 1.8 & 1.3 & 1.3 & 1.5 & 0.1 & -0.3 & -0.3 & 0.1 & -0.4 & -0.4 & \\
\hline Public sector debt-to-revenue ratio $2 /$ & 163.8 & 149.0 & 131.0 & 120.0 & 120.8 & 129.0 & 132.1 & 126.0 & 121.0 & 114.1 & 108.3 & \\
\hline Gross financing need $7 /$ & 7.3 & 9.1 & 10.5 & 9.0 & 6.8 & 8.0 & 7.7 & 5.4 & 4.3 & 4.4 & 3.9 & \\
\hline in billions of U.S. dollars & 8.3 & 13.1 & 17.1 & 18.7 & 16.3 & 18.3 & 19.0 & 14.1 & 12.0 & 13.0 & 12.5 & \\
\hline Scenario with key variables at their historical averages 8 / & & & & & & 34.0 & 30.9 & 28.5 & 26.5 & 24.2 & 21.7 & 0.2 \\
\hline Scenario with no policy change (constant primary balance) in 2009-2014 & & & & & & 34.0 & 35.2 & 35.3 & 35.1 & 35.5 & 35.1 & 1.0 \\
\hline \multicolumn{13}{|l|}{ Key Macroeconomic and Fiscal Assumptions Underlying Baseline } \\
\hline Real GDP growth (in percent) & 4.7 & 5.7 & 6.9 & 7.5 & 2.4 & 0.2 & 2.5 & 4.0 & 5.0 & 5.0 & 4.5 & \\
\hline Average nominal interest rate on public debt (in percent) 9/ & 10.0 & 8.9 & 11.4 & 12.7 & 11.9 & 11.3 & 11.4 & 10.2 & 10.6 & 10.9 & 11.5 & \\
\hline Average real interest rate (nominal rate minus change in GDP deflator, in percent) & 1.7 & 2.8 & 4.6 & 8.0 & 3.5 & 8.2 & 7.0 & 5.1 & 5.0 & 5.2 & 5.3 & \\
\hline Nominal appreciation (increase in US dollar value of local currency, in percent) & 16.3 & 4.6 & 2.0 & 11.1 & -10.4 & & & & 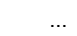 & & $\ldots$ & \\
\hline Inflation rate (GDP deflator, in percent) & 8.3 & 6.1 & 6.8 & 4.8 & 8.4 & 3.1 & 4.3 & 3.8 & 4.1 & 4.0 & 4.2 & \\
\hline Growth of real primary spending (deflated by GDP deflator, in percent) $10 /$ & -0.4 & 5.6 & 13.7 & 6.8 & -2.1 & 12.6 & -0.7 & 4.3 & 3.7 & 3.4 & 3.3 & \\
\hline Primary deficit & -3.0 & -3.2 & -3.0 & -3.0 & -3.6 & -0.5 & -0.5 & -1.1 & -1.6 & -2.0 & -2.0 & \\
\hline
\end{tabular}

\section{Source: Fund staff estimates.}

1/ Does not assume any drawings under the Flexible Credit Line arrangement.

2/ Indicate coverage of public sector, e.g., general government or nonfinancial public sector. Also whether net or gross debt is used.

$3 /$ Derived as $(r-\pi(1+g)-g+\alpha \varepsilon(1+r))(1+g+\pi+g \pi)$ limes previous period debt ratio, with $r=$ interest rate; $\pi=$ growth rate of GDP deflator; $g=$ real GDP growth rate; $\alpha=$ share of foreign-currency

denominaled debl, and 8 - nat a

Ther The

Tor projections, this line includes exchange rate changes.

7 pefined as public sector defict, exus amgertization of mes.

Defort-term debt at end of previous period.

8/ The key variables include real GDP growth; real interest rate; and primary balance in percent of GDP.

9/ Derived as nominal interest expenditure divided by previous period debt stock.

$11 /$ Assumes that key variables (real GDP growth, real interest rate, and other identified debt-creating flows) remain at the level of the last projection year. 
Press Release No. 09/367

International Monetary Fund

FOR IMMEDIATE RELEASE

Washington, D.C. 20431 USA

October 28, 2009

\section{IMF Executive Board Completes Review of Colombia's Performance under the Flexible Credit Line}

The Executive Board of the International Monetary Fund (IMF) today completed its sixmonth review of Colombia's qualification for the arrangement under the Flexible Credit Line (FCL). The Board reaffirmed Colombia's continued qualification to access FCL resources. The Colombian authorities have indicated they intend to continue treating the arrangement as precautionary and do not intend to draw on the line.

The one-year arrangement for Colombia of SDR 6.966 billion (about US\$11.13 billion) was approved on May 11, 2009 (See Press Release No. 09/161). Colombia was the third country to gain access to an FCL, following Mexico and Poland. The IMF designed the FCL for countries that have a history of sound macroeconomic policies and institutional frameworks. The FCL is designed to help countries' crisis efforts by providing the flexibility to draw on the credit line at any time. The FCL was created as part of an overhaul of the Fund's lending framework this spring (see Press Release No. 09/85 and Public Information Notice 09/40).

Following the Executive Board discussion of Colombia, Mr. John Lipsky, First Deputy Managing Director and acting Chairman of the Board, made the following statement:

"Last May, at a time of heightened global uncertainty, the IMF Executive Board approved an FCL arrangement for Colombia to serve as additional balance of payments protection, providing further room for the authorities to pursue countercyclical policies in the context of strong institutional policy frameworks. Developments since the FCL approval have been generally positive, financial market conditions have improved and perceptions of tail risks to the balance of payments have subsided.

"The upturn in the global environment has improved the outlook for the balance of payments and economic activity. Exports and remittances have performed better than anticipated as commodity prices recovered faster than expected. Roll-over rates, in particular for the public 
sector, also have been higher than previously anticipated. Against this background, economic recovery is taking hold, and growth for the year is expected to remain positive.

"Colombia's very strong institutional and policy frameworks provided scope to support domestic demand, with prudently expansionary macroeconomic policies. Since the FCL was approved, monetary policy has been eased further, while inflation expectations remained anchored; the exchange rate has continued to be an effective shock absorber; fiscal policy has helped sustain domestic demand, in particular through an increase in public investment; and, the financial system has continued to show resilience in the context of effective financial sector supervision. Looking ahead, monetary policy will continue to be guided by the inflation targeting framework and fiscal policy by a medium term framework, which should allow fiscal consolidation to restart by 2011.

"Against this backdrop of very strong policy frameworks and actions, the Executive Board today reaffirmed that Colombia continues to meet the qualification criteria for the FCL. Accordingly, access to resources under the FCL — which the authorities intend to continue to treat as precautionary_-will remain available as envisaged through May 2010," Mr. Lipsky said. 


\section{Statement by Maria Ines Agudelo, Alternate Executive Director for Colombia October 28, 2009}

My authorities believe that the FCL is an instrument that has played an important role by sending the correct signal when risks increased due to global uncertainties. When the FCL for Colombia was approved, the message was clear. The Fund said that "during the last decade, Colombia has maintained a very strong macroeconomic performance, underpinned by solid institutional policy frameworks" and that Colombia will have a significant amount of resources if needed to cover any financing shortages. The expectation was that with this support, external and local financing for both the public and private sectors should continue to flow and at a low cost, reducing the probability of the economy falling into even lower growth rates.

During the last six months, expectations have improved, confidence has returned and the effects of the external crisis have been contained. That does not mean that the country is not vulnerable to future external developments and that the recovery to healthy growth rates is assured. Future developments in advanced economies and in particular in our main commercial partners imply that the strength of the recovery is still uncertain. That does not mean either that the improved performance and expectations are only due to the FCL. However, I want to emphasize that thanks to the FCL there was more room for maneuver in terms of policy options to face the crisis and the external financial gap concerns have been reduced.

In fact, during the past six months the economy has been performing better than it was expected when the FCL was requested. Before recovering to a healthier 2.5 percent in 2010 , this year's growth will be in positive grounds, led by public consumption and investment. For next year, while the public sector will continue to be a driving force, current forecasts project that the private sector will follow a more dynamic pace.

As expected, exports have been strongly hit, but this has not translated into a significant deterioration of the current account balance. The current account deficit will remain roughly at 3 percent of GDP, the same level of the past recent years. Although the net financing of this deficit will temporarily rely on public sector financing, net foreign direct investment, in the baseline scenario, will amount to more than 2 percentage points of GDP in 2009 and for the medium term. During the first six months of this year, inflows of direct investment reached 5 billion dollars, more than half of what is expected for the whole year.

The Central Bank has reduced its interest rate by 600 basis points since December last year, 200 basis points since May. Headline inflation is at a record low, while core inflation is on a downward trend since the end of last year and is now just below this year's target range. At its most recent meeting, the Central Bank set its inflation target on its long-term target range of 2 to 4 percent. It is the first time since the inflation targeting framework was adopted in Colombia that the Bank sets its target in its medium-term objective.

During this phase of continuing monetary policy easing, the channels of transmission have operated in an effective way. Interest rates for the corporate sector and for households 
have decreased in nominal and real terms for all kinds of credit, with the exception of credit card interest rates. Credit and deposits continued to grow at real positive rates and the corporate sector has been successful in bonds' emissions in the local and external markets.

The exchange rate has been allowed to float, with no significant intervention in the foreign exchange market by the Central Bank, as it was understood that the exchange rate flexibility was a pillar of the countercyclical policy and a buffer of the external shock. Previous to our last discussion, the Colombian peso was on a depreciating trend. Since then the peso has been appreciating significantly (18 percent since end May) raising the concern of the government that has announced that they will stop any sale of foreign currency. Meanwhile the Central Bank might buy foreign exchange by intervening in the market discretionally as part of their strategy to provide liquidity to the economy.

The fiscal authorities' anti-cyclical strategy concentrates on several areas. Automatic stabilizers are operating, although not at their full magnitude (the increase of this year's fiscal deficit is lower than the revenues lost as a result of the slowdown of the economy), and public expenditure was prioritized towards infrastructure and to protect the most vulnerable. As it was discussed during the Article IV meeting, the emphasis of the authorities has been to reduce the vulnerability produced by the uncertainty of the external markets and by more fragile domestic markets that affect the public sector financing. In that sense, the authorities have been successful in accessing the international bond market to finance the 2010 budget, the last time two weeks ago by issuing a thirty-year bond ( 1 billion dollars) under favorable financial conditions. At the same time, the government has secured resources from multilateral institutions.

In June, the government presented to Congress the updated version of its medium-term fiscal framework. Under the current circumstances, the government recognized that the reduction of public debt, today at 32 percent of GDP, will deviate temporarily from the targeted reductions set last year. The authorities' new plan envisages that the current effect of the deteriorating fiscal results in 2009 and 2010 mean that the public debt will only resume its reduction path after 2014. However, the government has been clear in two fronts. First, deviations from the original path come from the loss of revenues due to a slower economic performance and not to an increase in public expenditure and, second, even taking into account the pressure that pension payments have placed on the budget, the government remains committed to a 1.2 percent primary surplus to meet its debt targets in the medium term.

The financial sector continues to be well capitalized and the banking sector remains solvent and profitable. During our discussion six months ago, NPL were on an upward trend, reflecting deteriorating conditions. Today, the picture has changed and NPL have now stabilized or are even on a downward trend.

To conclude, the FCL has been effective as an instrument that gives support to countries with strong fundamentals to weather the current international crisis. With a solid record of good policies and structural reforms, the Fund's support has boosted confidence and has given assurances that Colombia is well prepared to face the current strains of the external environment. 
On behalf of my authorities, I want to thank staff for the updated work on Colombia's economy that, as usual, faithfully reflects the evolving economic situation and the challenges that my authorities face. 